\title{
Epigenetic modification regulates both expression of tumor-associated genes and cell cycle progressing in human colon cancer cell lines: Colo-320 and SW1116
}

\author{
Jing Yuan FANG*, Ying Xuan CHEN, Juan LU, Rong LU, Li YANG, Hong Yin ZHU, Wei Qi GU, Lun Gen LU \\ Shanghai Institute of Digestive Disease, Renji Hospital Shanghai Second Medical University, Shanghai 200001, China.
}

\begin{abstract}
The aim of this study is to assess the effects of DNA methylation and histone acetylation, alone or in combination, on the expression of several tumor-associated genes and cell cycle progression in two established human colon cancer cell lines: Colo-320 and SW1116. Treatments with 5-aza-2'-deoxycytidine (5-aza-dC) and trichostatin A, alone or in combination, were applied respectively. The methylation status of the $C D K N 2 A$ promoter was determined by methylation-specific PCR, and the acetylated status of the histones associated with the $p 21^{\text {WAFI }}$ and $C D K N 2 A$ genes was examined by chromatin immunoprecipitation. The expression of the CDKN2A,p21 $1^{W A F 1}, p 53, p 73, A P C, c-m y c, c-K i$-ras and survivin genes was detected by real-time RT-PCR and RT-PCR. The cell cycle profile was established by flow cytometry.

We found that along with the demethylation of the $C D K N 2 A$ gene promoter in both cell lines induced by 5-aza-dC alone or in combination with TSA, the expression of both $C D K N 2 A$ and $A P C$ genes increased. The treatment of TSA or sodium butyrate up-regulated the transcription of $p 21^{W A F I}$ significantly by inducing the acetylation of histones $\mathrm{H} 4$ and $\mathrm{H} 3$, but failed to alter the acetylation level of $C D K N 2 A$-associated histones. No changes in transcription of $p 53, p 73$, c-myc, $c$-Ki-ras and survivin genes were observed. In addition, TSA or sodium butyrate was shown to arrest cells at the $\mathrm{G}_{1}$ phase. However, 5-aza-dC was not able to affect the cell cycle progression. In conclusion, regulation by epigenetic modification of the transcription of tumor-associated genes and the cell cycle progression in both human colon cancer cell lines Colo-320 and SW1116 is gene-specific.
\end{abstract}

Keywords: human colon cancer cell lines, tumor-associated genes, DNA methylation, histone acetylation, cell cycle.

\section{INTRODUCTION}

Colon cancer is one of the most commonly occurring tumors and a major cause of cancer-related deaths worldwide. Colon cancer cell lines Colo-320[1-3] and SW1116 [4-6] are frequently used in molecular biological experiments. The transcription of $C D K N 2 A[7], p 21^{\text {WAFI }}$ [8] and adenomatous polyposis coli $(A P C)[9]$ genes are down-regulated and $c$-myc proto-oncogene is over-expressed[10] in the Colo-320 cell line.

CDKN2A inhibits the catalytic activity of the cyclindependent kinases 4 (CDK4) /cyclin D complex and also blocks the $\mathrm{G}_{1} / \mathrm{S}$ transition in cells[11, 12]. p21 ${ }^{\mathrm{WAF} 1}$ is one

\footnotetext{
"Correspondence: Jing Yuan FANG,

Tel: +86-21-63200874, Fax: +86-21-63266027,

E-mail: jingyuanfang@yahoo.com
}

Abbreviations: 5-aza-dC, 5-aza-2'-deoxycytidine; HAT, histone acetyltransferase HDAC, histone deacetylase; APC, adenomatous polyposis coli; TSA, trichostatin A; SCFA, short chain fatty acid; CDK, cyclin-dependent kinase; CDKI, cyclin-dependent kinase inhibitor; Dnmt1, DNA methyltransferase 1 . of the CIP/KIP family, which inhibits late $\mathrm{G}_{1} / \mathrm{S}$ check point kinases. The increased expression of $\mathrm{p} 21^{\mathrm{WAF} 1}$ may induce growth arrest in transformed cells[13-15]. c-myc is a transcription factor whose normal function is to promote cell proliferation $[8,16]$.

Epigenetic modifications, mainly DNA methylation[17] and changes of histones, are now recognized as additional mechanisms contributing to malignant phenotypes[18]. Several studies have demonstrated that the inactivation of CDKN2A in human colon tissue may be due to de novo methylation of its 5' promoter-associated CpG island[1923].

Hyperacetylation of histones has been shown to open chromatin and is required for transcriptional activation[24]. Because the inhibitory effects of complex endogenous genes may play a significant role in the $\mathrm{G}_{1}-\mathrm{S}$ progression of the cell cycle, histone deacetylases (HDAC) inhibitors, trichostatin A (TSA, a hybrid polar compound specific inhibitor)[24-26] and sodium butyrate (butyrate, a short chain fatty acid, SCFA)[27-29] have been considered as candi- 
dates for the treatment of cancer[20].

Previous studies focused on aberrant methylation or acetylation alone in a single gene. However, little is known about the effect of the regulation of methylation and histone acetylation on the expression of several tumor-associated genes including the tumor suppressor gene and proto-oncogene in human colon cancer. The DNA methylation status, gene-associated-histone acetylation pattern and the transcriptional level of tumor-associated genes in the presence of combined 5-aza-dC and HDAC inhibitors in the Colo-320 and SW1116 cell lines remain unclear. Furthermore, we want to know whether 5-aza-dC or TSA induces over-expression of proto-oncogene while regulating the transcription of tumor suppressor genes. The aim of this study is to gain a better understanding of the effect of the regulation of DNA methylation and histone acetylation on the regulation of tumor suppressor gene and proto-oncogene transcription.

\section{MATERIALS AND METHODS}

\section{Cell culture}

The colon cancer-derived cell lines Colo-320 and SW1116 were maintained by serial passages in RPMI 1640 containing $10 \%$ heatinactivated FCS, $100 \mathrm{U} / \mathrm{ml}$ penicillin and $100 \mu \mathrm{g} / \mathrm{ml}$ streptomycin, and incubated at $37^{\circ} \mathrm{C}, 5 \% \mathrm{CO}_{2}-95 \%$ air using standard tissue culture incubators as described previously[30].

\section{Treatment with 5-aza-dC, TSA and butyrate}

5 -aza-dC is an inhibitor of DNA methyltransferase (Dnmt 1) [31], but TSA and butyrate are HDAC inhibitors. To assess the restoration of $C D K N 2 A, p 21^{W A F 1}, A P C, p 53, p 73, c-m y c, c-K i$-ras and survivin genes expression by 5 -aza-dC, TSA or butyrate treatment, the colon cancer cell lines were exposed to different concentrations $(2 \mu \mathrm{M}, 5 \mu \mathrm{M}$ or $10 \mu \mathrm{M})$ of 5 -aza-dC (Sigma, St. Louis, $\mathrm{MO}$ ) alone for $24 \mathrm{~h}$ and $72 \mathrm{~h} ; 1 \mu \mathrm{M}$ TSA or $5 \mu \mathrm{M}$ butyrate (Sigma, St. Louis, MO) alone for $24 \mathrm{~h}$. For the combined treatment of drugs, cells were incubated with $10 \mu \mathrm{M}$ of 5 -aza-dC for $2 \mathrm{~d}$ and then with $1 \mu \mathrm{M}$ of TSA or $5 \mu \mathrm{M}$ of sodium butyrate for $24 \mathrm{~h}$. The control cultures were treated with phosphate-buffered saline (PBS) or ethanol (for TSA treatment, because TSA can only be dissolved in PBS containing ethanol). DNA and RNA were extracted at various time points.

\section{Cell viability assays}

The 3-(4,5-Dimethylthiazol-2-yl)-2,5-diphenytetrazolium (MTT) assay measures both cytostatic and cytotoxic responses to drug treatment and thus provides an accurate overall measure of drug sensitivity. Cell viability assays were performed in quadruplicate wells of 24-well plates $3 \mathrm{~d}$ after the treatment of 5-aza-dC or TSA or sodium butyrate. MTT (Calbiochem, San Diego, CA) assay was used to assess drug-induced cell growth inhibition and cytotoxicity. No significant cytotoxic damage was observed during the drug treatment.

\section{Bisulfite modification and methylation-specific PCR (MSP) for $C D K N 2 A$ promoter}

To address whether DNA methylation of $C D K N 2 A$ changed during the drug treatment, we carried out bisulfite modification[32] and MSP to define a CpG-rich region in the $C D K N 2 A$ gene promoter.

Bisulfite converts unmethylated cytosine residues to uracil, but methylated cytosines remain nonreactive. PCR amplifies uracil as thymine while methylated cytosines can only be amplified as cytosines. Genomic DNA treated by bisulfite was amplified with $C D K N 2 A$ promoter gene fragment specific primers. PCR reaction buffer contained $0.1 \mathrm{mM} \mathrm{dNTP}, 2.0 \mathrm{mM} \mathrm{MgCl}{ }_{2}$, and $0.5 \mu \mathrm{M}$ primers. PCR product was directly loaded on to $3 \%$ agarose gels and electrophoresed. The gel was stained with ethidium bromide and directly visualized under UV illumination. The sequences and PCR program are shown in Tab 1. Furthermore, wild-type $C D K N 2 A$ primers were used to monitor the complete conversion of DNA obtained in the bisulfite reaction.

\section{Chromatin immunoprecipitation (ChIP) assay}

A ChIP assay kit from Upstate Biotechnology was used according to the manufacturer's protocol and Richon's report[33]. Colo320 and SW1116 cells, mock-treated and treated with drugs, were plated at a density of $10 \times 10^{6}$ cells/T25 flask. $p 21^{W A F I}$ - and $C D K N 2 A$ -specific primers were used to carry out PCR. The density of bands in ChIP-PCR was quantitated using a Molecular Dynamics PhosphorImager (Nucleo Tech Inc, San Mateo, CA). The sequences of one set of primers for $C D K N 2 A$ and two sets of primers for $p 21^{\text {WAFl }}$ PCR, as well as the PCR condition are shown in Tab 1 . The $1^{\text {st }}$ set of primers was used to amplify -576 to -293 and the $2^{\text {nd }}$ set of primers was used to amplify -51 to +77 of $p 21^{\text {WAFI }}$ promoter and exon 1, which contained the transcription factor E2A binding sites. The 395 bp band corresponds to the promoter of CDKN2A $(21 \mathrm{CpG}$ sites, positions -494 to -101$)[34]$.

\section{Reverse transcription polymerase chain reaction (RT-PCR)}

Total RNA was extracted by using a commercial kit (Trizol) according to the manufacturer's instructions (Gibco BRL). RT reactions using $5 \mu \mathrm{g}$ of total RNA were performed with Superscript II reverse transcriptase (Life Technologies, Inc.). The mRNA transcription levels of $p 53, p 73, c-$ Ki-ras and survivin genes were determined by RT-PCR. The sequences and PCR reaction for each primer are shown in Tab 1. For the control of RT-PCR, a 612 bp fragment of $\beta$ actin cDNA was also amplified.

\section{Real-time quantitative PCR}

The mRNA levels of $C D K N 2 A, p 21^{\text {WAF1 }}, A P C$ and $c$-myc were measured using a real-time quantitative PCR system. Relative quantitation using the comparative $\mathrm{Ct}$ method with data from the ABI PRISM 7700 Sequence Detection System (version 1.6 software) was performed according to the manufacturer's protocol. The primers and Taqman fluorogenic probes for $C D K N 2 A, p 21^{W A F 1}, A P C$ and $c$ $m y c$ were provided by Shenyou Company, Shanghai. The sequences of forward and reverse primers and the probes are shown in Tab 2. Real-time PCR was also performed with primers and Taqman $\beta$ actin probes to normalize each of the extracts for amplifiable human DNA. The results were expressed as the ratio of copies of $C D K N 2 A$, $p 21^{W A F 1}, A P C$ and $c$-myc to $\beta$-actin, respectively. The $\mathrm{Ct}$ values were 
Tab 1. Sequences and PCR programs of primers for RT-PCR, sequencing and ChIP-PCR

\begin{tabular}{|c|c|c|c|c|c|}
\hline Gene & Reactions & $\begin{array}{l}\text { Primer (Sense) } \\
\quad\left(5^{\prime} \rightarrow 3^{\prime}\right)\end{array}$ & $\begin{array}{l}\text { Primer (Antisense) } \\
\quad\left(5^{\prime} \rightarrow 33^{\prime}\right)\end{array}$ & $\begin{array}{l}\text { Size and PCR } \\
\text { condition }\end{array}$ & $\begin{array}{l}\text { GenBank } \\
\text { accession } \\
\text { number }\end{array}$ \\
\hline$\beta$-actin & RT-PCR & $\begin{array}{l}\text { GGC ATC GTG ATG } \\
\text { GAC TCC G }\end{array}$ & $\begin{array}{l}\text { GCT GGA AGG } \\
\text { TGG ACA GCG A }\end{array}$ & $\begin{array}{l}612 \mathrm{bp} \\
92^{\circ} \mathrm{C} 40 \mathrm{sec}, 58^{\circ} \mathrm{C} 40 \mathrm{sec}, 72^{\circ} \mathrm{C} 50 \mathrm{sec}, \\
30 \text { cycles }\end{array}$ & ВC023204 \\
\hline$c-K i-r a s$ & RT-PCR & $\begin{array}{l}\text { ATG ACT } \\
\text { GAA TAT AAA } \\
\text { CTT GTG GTA }\end{array}$ & $\begin{array}{l}\text { TGT CTT GTC } \\
\text { TTT GCT GAT } \\
\text { GTT TCA }\end{array}$ & $\begin{array}{l}449 \mathrm{bp} \\
95^{\circ} \mathrm{C} 30 \mathrm{sec}, 55^{\circ} \mathrm{C} 30 \mathrm{sec}, 72^{\circ} \mathrm{C} 30 \mathrm{sec}, \\
35 \text { cycles }\end{array}$ & M54968 \\
\hline survivin & RT-PCR & $\begin{array}{l}\text { ATT CGT CCG } \\
\text { GTT GCG CTT } \\
\text { TCC TTT }\end{array}$ & $\begin{array}{l}\text { TTC CTA AGA } \\
\text { CAT TGC TAA } \\
\text { GGG GCC }\end{array}$ & $\begin{array}{l}297 \mathrm{bp} \\
94^{\circ} \mathrm{C} 1 \mathrm{~min}, 55^{\circ} \mathrm{C} 1 \mathrm{~min}, 72^{\circ} \mathrm{C} 1 \mathrm{~min}, \\
35 \text { cycles }\end{array}$ & U 75285 \\
\hline$p 53$ & RT-PCR & $\begin{array}{l}\text { CAG CCA AGT } \\
\text { CTG TGA CTT } \\
\text { GCA CGT AC }\end{array}$ & $\begin{array}{l}\text { CTA TGT CGA } \\
\text { AAA GTG TTT } \\
\text { CTG TCA TC }\end{array}$ & $\begin{array}{l}292 \mathrm{bp} \\
94^{\circ} \mathrm{C} 30 \mathrm{sec}, 65^{\circ} \mathrm{C} 1 \mathrm{~min}, 72^{\circ} \mathrm{C} 1 \mathrm{~min}, \\
35 \text { cycles }\end{array}$ & XM008679 \\
\hline$p 73$ & RT-PCR & $\begin{array}{l}\text { AAC GCT GCC } \\
\text { CCA ACC ACG } \\
\text { AG }\end{array}$ & $\begin{array}{l}\text { GCC GGT TCA } \\
\text { TGC CCC CTA } \\
\text { CA }\end{array}$ & $\begin{array}{l}226 \mathrm{bp} \\
95^{\circ} \mathrm{C} 30 \mathrm{sec}, 60^{\circ} \mathrm{C} 30 \mathrm{sec}, 72^{\circ} \mathrm{C} 30 \mathrm{sec}, \\
35 \text { cycles }\end{array}$ & Y11416 \\
\hline$C D K N 2 A$ & Methyl-MSP & $\begin{array}{l}\text { TTA TTA GAG } \\
\text { GGT GGG GCG } \\
\text { GAT CGC }\end{array}$ & $\begin{array}{l}\text { GAC CCC GAA } \\
\text { CCG CGA CCG } \\
\text { TAA }\end{array}$ & $\begin{array}{l}150 \mathrm{bp} \\
95^{\circ} \mathrm{C} 1 \mathrm{~min}, 65^{\circ} \mathrm{C} 1 \mathrm{~min}, 72^{\circ} \mathrm{C} 1 \mathrm{~min} \text {, } \\
40 \text { cycles }\end{array}$ & X94154 \\
\hline$C D K N 2 A$ & Unmethyl-MSP & $\begin{array}{l}\text { TTA TTA GAG } \\
\text { GGT GGG GTG } \\
\text { GAT TGT }\end{array}$ & $\begin{array}{l}\text { CAA CCC CAA } \\
\text { ACC ACA ACC } \\
\text { ATA A }\end{array}$ & $\begin{array}{l}151 \mathrm{bp} \\
95^{\circ} \mathrm{C} 1 \mathrm{~min}, 60^{\circ} \mathrm{C} 1 \mathrm{~min}, 72^{\circ} \mathrm{C} 1 \mathrm{~min}, \\
40 \text { cycles }\end{array}$ & X94154 \\
\hline $\begin{array}{l}p 21^{\text {WAFl }} \\
\mathrm{p} 1\end{array}$ & ChIP-PCR & $\begin{array}{l}\text { CGT GGT GGT } \\
\text { GGT GAG CTA } \\
\text { GA }\end{array}$ & $\begin{array}{l}\text { CTG TCT GCA } \\
\text { CCT TCG CTC } \\
\text { CT }\end{array}$ & $\begin{array}{l}296 \mathrm{bp} \\
95^{\circ} \mathrm{C} 1 \mathrm{~min}, 56^{\circ} \mathrm{C} 1 \mathrm{~min}, 72^{\circ} \mathrm{C} 1 \mathrm{~min}, \\
35 \text { cycles }\end{array}$ & U 24170 \\
\hline $\begin{array}{l}p 21^{\text {WAF1 }} \\
\mathrm{p} 2\end{array}$ & ChIP-PCR & $\begin{array}{l}\text { GGT TGT ATA } \\
\text { TCA GGG CCG }\end{array}$ & $\begin{array}{l}\text { CTC TCA CCT } \\
\text { CCT CTG AGT } \\
\text { GC }\end{array}$ & $\begin{array}{l}128 \mathrm{bp} \\
95^{\circ} \mathrm{C} 1 \mathrm{~min}, 52^{\circ} \mathrm{C} 1 \mathrm{~min}, 72^{\circ} \mathrm{C} 1 \mathrm{~min} \text {, } \\
35 \text { cycles }\end{array}$ & U 24170 \\
\hline$C D K N 2 A$ & ChIP-PCR & $\begin{array}{l}\text { GGG CTC TCA } \\
\text { CAA CTA GGA }\end{array}$ & $\begin{array}{l}\text { CGG AGG AGG } \\
\text { TGC TAT TAA } \\
\text { CTC }\end{array}$ & $\begin{array}{l}395 \mathrm{bp} \\
95^{\circ} \mathrm{C} 1 \mathrm{~min}, 58^{\circ} \mathrm{C} 1 \mathrm{~min}, 72^{\circ} \mathrm{C} 1 \mathrm{~min} \text {, } \\
40 \text { cycles }\end{array}$ & AF527803 \\
\hline
\end{tabular}

measured, and the average $\mathrm{Ct}$ of triplicate samples was calculated. Alteration of mRNA expression was defined as a 3 -fold difference in the expression level after treatment, relative to that before treatment [35].

\section{Flow cytometric (FCM) detection of cell cycle}

Cell cycle analysis was carried out by FCM[36]. In brief, a total of $1 \times 10^{8}$ cells were removed from the treated and mock-treated cultures at specified time points. The cells were washed twice with PBS and fixed in ice-cold ethanol for $1 \mathrm{~h}$. The samples were concentrated by removing ethanol and treated with $1 \%(\mathrm{v} / \mathrm{v})$ Triton X-100 (Sigma,
USA) and $0.01 \%$ RNase (mg/ml, sigma, St. Louis, Mo.) for $10 \mathrm{~min}$ at $37^{\circ} \mathrm{C}$. The staining of cellular DNA was performed with $0.05 \%$ propidium iodide for $20 \mathrm{~min}$ at $4{ }^{\circ} \mathrm{C}$ in darkness. The cell cycle distribution was detected using a flow cytometer (Model FACSCALIBAR, BD, USA) and 10,000 cells were analyzed with the MultiCycle software package (Phoenix, San Diego, CA, USA).

\section{Statistical analysis}

Differences in the cell cycle between those cells treated with drugs and those mock-treated were analyzed by the Fisher exact test. 
Tab 2. Sequence of primers and probes for real-time PCR

\begin{tabular}{|c|c|c|c|c|}
\hline Gene & $\begin{array}{l}\text { Primer (Sence) } \\
\qquad\left(5^{\prime} \rightarrow 3^{\prime}\right)\end{array}$ & $\begin{array}{l}\text { Primer (Antisense) } \\
\qquad\left(5^{\prime} \rightarrow 3^{\prime}\right)\end{array}$ & Probe & GenBank No \\
\hline$C D K N 2 A$ & $\begin{array}{l}\text { CAT AGA TGC } \\
\text { CGC GGA AGG } \\
\mathrm{T}\end{array}$ & $\begin{array}{l}\text { CAG AGC CTC } \\
\text { TCT GGT TCT } \\
\text { TTC AA }\end{array}$ & $\begin{array}{l}\text { CCT CAG ACA } \\
\text { TCC CCG }\end{array}$ & NM_058197 \\
\hline$p 21^{\text {WAFI }}$ & $\begin{array}{l}\text { CTG GAG ACT } \\
\text { CTC AGG GTC } \\
\text { GAA }\end{array}$ & $\begin{array}{l}\text { GGA TTA GGG } \\
\text { CTT CCT CTT } \\
\text { GGA }\end{array}$ & $\begin{array}{l}\text { ACG GCG GCA } \\
\text { GAC CAG CAT } \\
\text { GA }\end{array}$ & NM_078467 \\
\hline$A P C$ & $\begin{array}{l}\text { TTG ACA AAC } \\
\text { TTG ACT TTT } \\
\text { GGA GAT G }\end{array}$ & $\begin{array}{l}\text { CAT GCA GCC } \\
\text { TTT CAT AGA } \\
\text { GCA T }\end{array}$ & $\begin{array}{l}\text { AGC CAA CAA } \\
\text { GGC TAC }\end{array}$ & NM_000038 \\
\hline$c-m y c$ & $\begin{array}{l}\text { ACA CCG CCC } \\
\text { ACC ACC AG }\end{array}$ & $\begin{array}{l}\text { CCA CAG AAA } \\
\text { CAA CAT CGA } \\
\text { TTT CTT }\end{array}$ & $\begin{array}{l}\text { AGC GAC TCT } \\
\text { GAG GAG G }\end{array}$ & V00568 \\
\hline$\beta$-actin & $\begin{array}{l}\text { CTG GCA CCC } \\
\text { AGC ACA ATG }\end{array}$ & $\begin{array}{l}\text { GGA CAG CGA } \\
\text { GGC CAG GAT }\end{array}$ & $\begin{array}{l}\text { ATC ATT GCT } \\
\text { CCT CCT GAG }\end{array}$ & ВC016045 \\
\hline
\end{tabular}

\section{RESULTS}

\section{Demethylation of promoter and the restoration of expression of $C D K N 2 A$ gene by 5 -aza-dC}

In the first part of this study, we examined the possibility of methylation in regulating the expression of $C D K N 2 \mathrm{~A}$ in Colo-320 and SW1116 cells. As shown in Fig 1, mocktreated Colo-320 and SW1116 cells showed a positive 150 bp band and $151 \mathrm{bp}$ band for methylated and unmethylated specific primer sets for $C D K N 2 A$ respectively, indicating that the $C D K N 2 A$ gene is partially methylated in the tested cell lines. The methylated bands of $C D K N 2 A$ gene in the cells treated with $10 \mu \mathrm{M}$ of 5-aza-dC for $24 \mathrm{~h}$ were consistently lower than those of the mock-treated cells (Fig 1). Thus, unmethylated product was significantly higher in the 5-aza-dC treated cells. The data from this study showed that untreated Colo-320 and SW1116 cells were methylated at some $\mathrm{CpG}$ sites in most alleles. After treatment with $10 \mu \mathrm{M}$ of 5 -aza-dC, the cytosine (C) in $\mathrm{CpG}$ changed to thymine $(\mathrm{T})$ in some sites.

As shown in Tab 3, 5-aza-dC in a higher concentration $(10 \mu \mathrm{M})$ induced transcription of $C D K N 2 A$ at $24 \mathrm{~h}$, but not in a lower concentration $(2 \mu \mathrm{M}$ or $5 \mu \mathrm{M})$. In contrast, at $72 \mathrm{~h}$ post-treatment, the level of $C D K N 2 A$ mRNA of cells exposed to 5-aza-dC was less than that at $24 \mathrm{~h}$.

However, the transcription of the $C D K N 2 A$ gene can be induced by 5 -aza-dC alone but not by TSA alone or the combination of 5-aza-dC and TSA. Also the treatment of TSA or sodium butyrate failed to induce the acetylation of

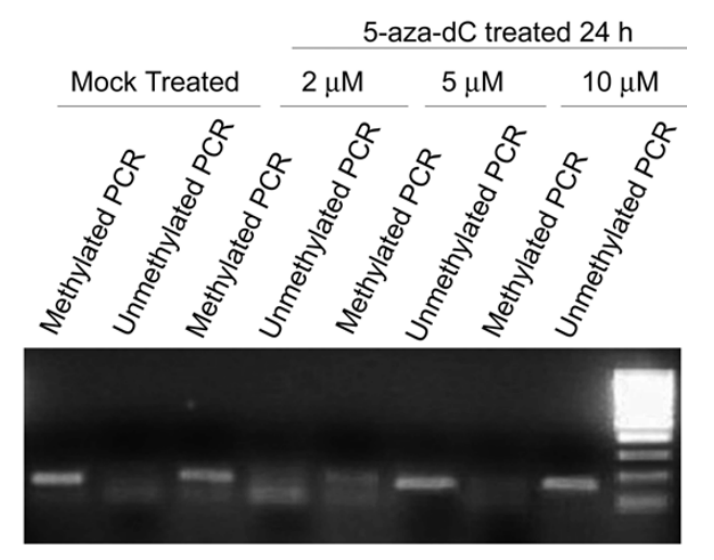

Fig 1. Methylation analysis of $C D K N 2 A$ gene promoter by MSP. MSP was performed with the specific primers described in the Materials and Methods.

histones $\mathrm{H} 3$ and $\mathrm{H} 4$ in colon cancer cells (Fig 2C). Thus, the above results indicate that DNA methylation but not histone acetylation is the major regulating mechanism for $C D K N 2 A$ expression in human colon cancer cell lines.

\section{5-aza-dC but not TSA or sodium butyrate increased the transcription of the $A P C$ gene}

To identify whether the transcription level of $A P C$ is regulated by DNA methylation or histone acetylation or both in human colon cancer cells, $A P C$ mRNA level was assayed. Colo-320 and SW1116 cells were cultured with 


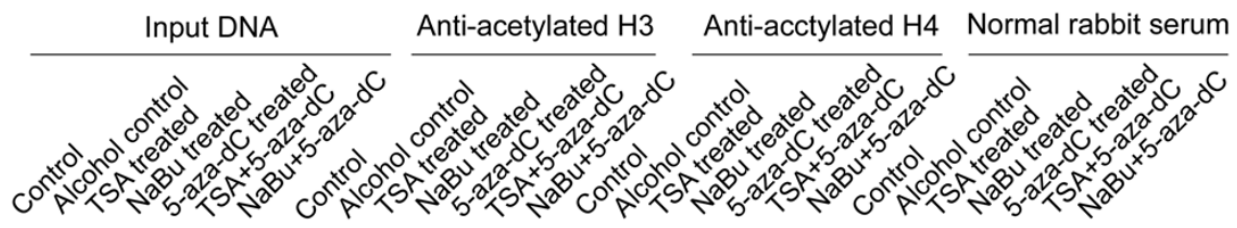

A

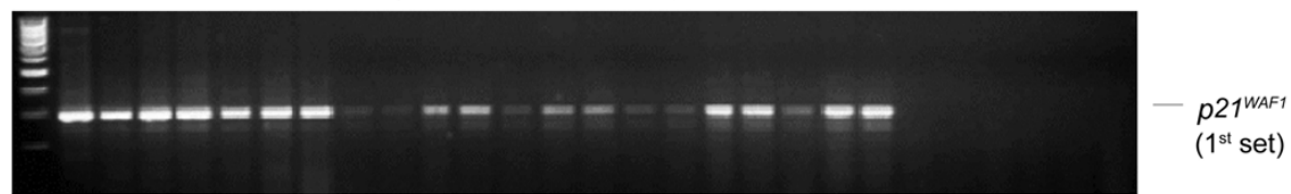

B

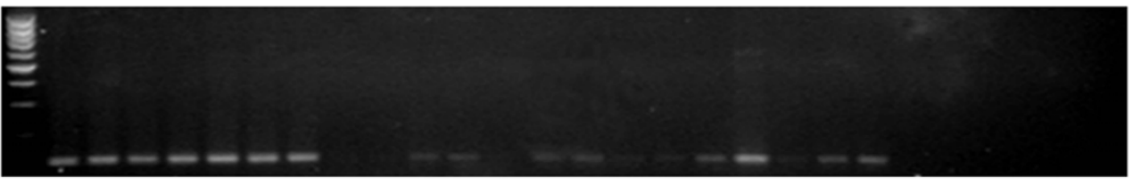

C

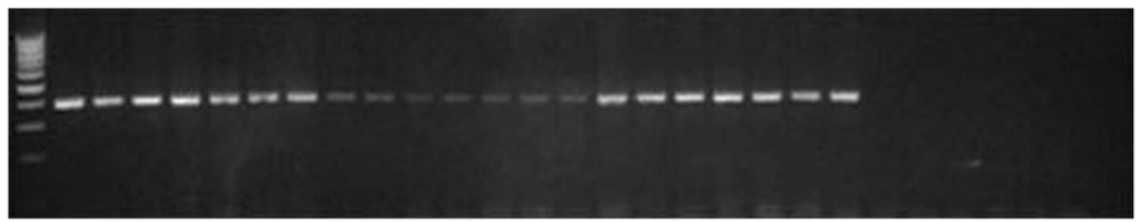

D $p 21^{\text {WAFI }}$-assocaited histones acetylation ${ }^{*}$

\begin{tabular}{llllccc}
\hline \multirow{2}{*}{ Drugs } & & \multicolumn{5}{c}{ IP.DNA/Input DNA } \\
\cline { 3 - 7 } & & TSA & NaBu & 5-aza-dC & TSA+aza & NaBu+aza \\
\hline Fold & Anti-H3 & 1.80 & 2.01 & 1.12 & 2.08 & 1.84 \\
increased & Anti-H4 & 2.17 & 2.53 & 1.29 & 2.91 & 3.10 \\
\hline
\end{tabular}

*Because the density of bands from the control and the ethanol control in PCR using $2^{\text {nd }}$ set primers were not detected,the data indicated in table was the result from ChIP-PCR using $1^{\text {st }}$ set primers only.

Fig 2. TSA and sodium butyrate $(\mathrm{NaBu})$ but not 5 -aza-dC induced accumulation of acetylated histones $\mathrm{H} 3$ and $\mathrm{H} 4$ in $p 21^{\text {WAF1 }}$ gene but not $C D K N 2 A$. Soluble chromatin from Colo-320 cells treated with or without TSA or NaBu or 5-aza-dC was immunopreciptated with antiacetylated histones $\mathrm{H} 3$ and $\mathrm{H} 4$ antibodies. The $1^{\text {st }}(\mathbf{A})$ and the $2^{\text {nd }}(\mathbf{B})$ sets PCR primers for the regions of $p 21^{\text {WAFl }}$, and $(\mathbf{C})$ were PCR primers for the promoter of $C D K N 2 A$ as indicated in Materials and Methods. (D) The Figs in A and B were scanned and quantified by Molecular Dynamics PhosphorImager. The ratio between input DNA and precipitated DNA was calculated for each treatment and primer set. The folds increased after treatment with TSA or $\mathrm{NaBu}$ or 5-aza-dC were calculated from the indicated ratios.

or without 5-aza-dC or TSA or sodium butyrate for $24 \mathrm{~h}$ and $72 \mathrm{~h}$. An incubation of $24 \mathrm{~h}$ with 5 -aza-dC resulted in the accumulation of $A P C$ mRNA, which remained at a higher level during a $72 \mathrm{~h}$ incubation period. The $A P C$ mRNA levels were normalized with $\beta$-actin mRNA (Tab 3 ). The effect of 5-aza-dC on the expression of $A P C$ was high even at a very low dosage $(2 \mu \mathrm{M}$ for Colo-320 and $5 \mu \mathrm{M}$ for SW1116 cells), suggesting that methylation-induced silencing of this gene was the primary event. The restoration of $A P C$ expression by 5-aza-dC confirmed a causal relationship between DNA hypermethylation and $A P C$ silencing in colon cancer cell lines Colo-320 and SW1116.
No obvious change was seen during the treatment with TSA or sodium butyrate. The expression of the housekeeping gene $\beta$-actin was used as a control to ensure the similarity in quality and quantity of RNA samples amplified by real-time RT-PCR.

Either TSA or sodium butyrate but not 5-aza-dC induced the acetylation of $p 21^{W A F 1}$ gene-associated histones and the re-expression of $p 21^{W A F 1}$

To determine whether histone acetylation affects $p 21^{\text {WAFI }}$ transcription, and whether a functional interaction occurs between $p 21^{W A F 1}$ and TSA or sodium butyrate treatment, ChIP-PCR was performed. The input was $10 \%$ of the 
Tab 3. Alteration of mRNA expression of $C D K N 2 A, p 21^{\text {WAF1 }}, A P C, c-m y c$ and $\beta$-actin in Colo- 320 and SW1116 cells, using real-time quantitative PCR

\begin{tabular}{|c|c|c|c|c|c|c|c|c|}
\hline \multirow[t]{2}{*}{ Groups } & \multicolumn{2}{|c|}{$C D K N 2 A$} & \multicolumn{2}{|c|}{$p 21^{W A F 1}$} & \multicolumn{2}{|c|}{$A P C$} & \multicolumn{2}{|c|}{$c-m y c$} \\
\hline & Colo-320 & SW1116 & Colo-320 & SW1116 & Colo-320 & SW1116 & Colo-320 & SW1116 \\
\hline Mock control & 1.00 & 1.00 & 1.00 & 1.00 & 1.00 & 1.00 & 1.00 & 1.00 \\
\hline Ethanol control & 1.00 & 1.00 & 1.00 & 1.00 & 1.00 & 1.00 & 1.00 & 1.00 \\
\hline \multicolumn{9}{|l|}{ 5-aza-dC treated } \\
\hline $2 \mu \mathrm{M}, 24 \mathrm{~h}$ & 1.72 & 1.05 & 0.37 & 0.73 & $4.66^{*}$ & 1.24 & 0.88 & 0.72 \\
\hline $5 \mu \mathrm{M}, 24 \mathrm{~h}$ & 2.77 & 1.65 & 0.47 & 0.73 & 1.01 & $3.71^{*}$ & 0.81 & 1.07 \\
\hline $10 \mu \mathrm{M}, 24 \mathrm{~h}$ & $3.41^{*}$ & $3.76^{*}$ & 0.45 & 1.09 & 1.30 & 0.81 & 0.93 & 0.67 \\
\hline $2 \mu \mathrm{M}, 72 \mathrm{~h}$ & 1.00 & 1.73 & 0.38 & 1.46 & 1.87 & 1.38 & 0.73 & 1.19 \\
\hline $5 \mu \mathrm{M}, 72 \mathrm{~h}$ & 1.22 & 1.85 & 0.98 & 1.03 & $3.05^{*}$ & 1.93 & 1.36 & 0.96 \\
\hline $10 \mu \mathrm{M}, 72 \mathrm{~h}$ & 2.81 & 1.74 & 0.76 & 1.44 & 2.81 & $3.03^{*}$ & 1.09 & 1.10 \\
\hline TSA & 0.77 & 0.85 & $27.1^{*}$ & $6.72^{*}$ & 1.59 & 0.69 & 0.52 & 0.90 \\
\hline Sodium butyrate & 0.52 & 1.16 & $17.15^{*}$ & $3.63^{*}$ & 1.69 & 0.71 & 0.45 & 0.97 \\
\hline TSA +5-aza-dC & 1.42 & 1.02 & $30.70^{*}$ & $6.82^{*}$ & $4.26^{*}$ & 0.95 & 1.17 & 0.99 \\
\hline Butyrate +5 -aza-dC & 1.29 & 1.25 & $16.11^{*}$ & $3.41^{*}$ & $3.14^{*}$ & 1.13 & 1.57 & 1.16 \\
\hline
\end{tabular}

Reverse transcription of total RNA from Colo-320 and SW1116 cells and subsequent amplification of cDNA resulted in 56- ,98-, 66-, and $73 \mathrm{bp}$ fragments for $C D K N 2 A, p 21^{W A F 1}, A P C$, and $c$-myc, respectively. Using real-time quantitative PCR with $\beta$-actin (93 bp) as internal standard. *Alteration of mRNA expression was defined as a 3 -fold difference in the transcription level in colon cancer cell lines after treatment relative to before treatment.

amount of chromatin which was used for immunoprecipitation.

As shown in Fig 2, the densities of bands of $p 21^{\text {WAFl }}$ gene-associated acetylated histone $\mathrm{H} 4$ and $\mathrm{H} 3$ were higher in chromatin extracted from either TSA or sodium butyrate treated Colo- 320 cells than that from mock-treated cells. 285 - and $128 \mathrm{bp}$ fragments of $p 21^{\text {WAFI }}$ promoter region and exon 1 were amplified (Fig $2 \mathrm{~A}$ and $2 \mathrm{~B}$ ). In the PCR product containing transcription factor E2A binding sites of promoter region, the positive bands that were not detected in controls were found after being cultured with TSA or sodium butyrate.

On the other hand, sodium butyrate or TSA or both combined with 5 -aza-dC greatly increased the $p 21^{W A F I}$ transcription level in the cells. As shown in Tab 3, after treatment with 5-aza-dC alone, there was no significant difference between the expression of this gene in cells treated with and without drugs. In addition, in Colo-320 cells, $p 21^{\text {WAFI }}$ expression increased to a higher level than that in SW1116 cells.

Taken together, the above results indicated that TSA or sodium butyrate activated the transcription of $p 21^{\text {WAFI }}$ through acetylating histones $\mathrm{H} 4$ and $\mathrm{H} 3$ associated with the $p 21^{\text {WAFI }}$ promoter.

5-aza-dC or TSA or sodium butyrate treatment failed to induce expression of $p 53, p 73, c-m y c, c$ $K i$-ras and survivin in Colo-320 and SW1116 cells

To further define the modification status of proto-
Tab 4. TSA and sodium butyrate induce the arrest of G1 to S phase in SW1116 cells

\begin{tabular}{lccc}
\hline Treatment & $\begin{array}{c}\mathrm{G}_{0} / \mathrm{G}_{1} \text {-phase } \\
(\%)\end{array}$ & $\begin{array}{c}\text { S-phase } \\
(\%)\end{array}$ & $\begin{array}{c}\mathrm{G}_{2} / \mathrm{M} \text {-phase } \\
(\%)\end{array}$ \\
\hline Mock treatment & $34.6 \pm 4.8$ & $37.2 \pm 1.7$ & $28.2 \pm 6.6$ \\
Ethanol control & $30.3 \pm 4.6$ & $38.8 \pm 2.8$ & $31.0 \pm 6.3$ \\
TSA treatment & $85.9 \pm 3.6^{* *}$ & $4.8 \pm 0.1^{* *}$ & $9.4 \pm 3.6^{* *}$ \\
Butyrate treatment & $88.6 \pm 1.8^{* *}$ & $5.0 \pm 0.5^{* *}$ & $6.4 \pm 1.4^{* *}$ \\
5-aza-dC treatment & $39.1 \pm 1.7$ & $36.5 \pm 1.7$ & $24.4 \pm 3.4$ \\
TSA + 5-aza-dC & $89.6 \pm 1.8^{* *}$ & $4.6 \pm 0.5^{* *}$ & $5.8 \pm 1.9^{* *}$ \\
Sodium butyrate & $89.8 \pm 1.3^{* *}$ & $5.1 \pm 0.7^{* *}$ & $5.1 \pm 1.9^{* *}$ \\
$\quad$ & & \\
\hline
\end{tabular}

Cell cycle analysis was performed by FCM. TSA and sodium butyrate induce histone hyperacetylation and the re-expression of $p 21^{\text {WAFI }}$, and induce a arrest of $\mathrm{G}_{1} \rightarrow \mathrm{S}$ phase in SW1116 cells. mRNA from mock treatment (or ethanol control) $v s$ that from drugs treatment, ${ }^{* *} P<0.01$, Fisher exact test.

oncogene $c$-myc overexpression in colon cancer cells, we attempted to clarify whether $c-m y c$ expression is altered after treatment with Dnmt inhibitor or HDAC inhibitors. Although the significant overexpression of $c-m y c$ and $c$ Ki-ras has been found in mock-treated Colo-320 and SW1116 cells, our current study revealed that almost no change in transcription was seen when these two cell lines were treated by 5 -aza-dC or TSA or sodium butyrate. In other words, no evidence was found that 5 -aza-dC and 
A

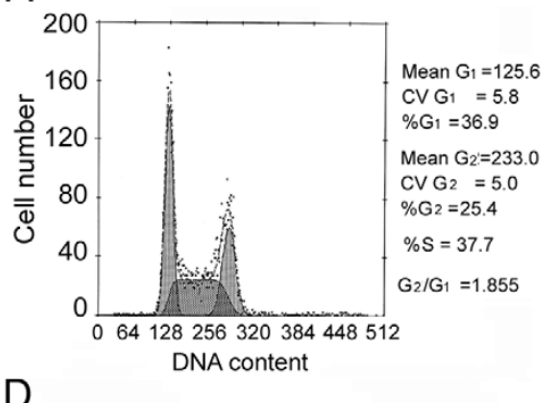

$\mathrm{D}$

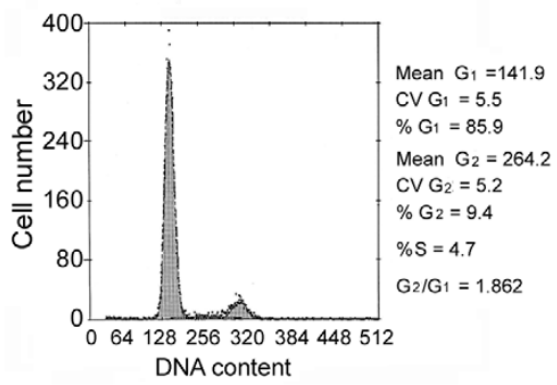

G

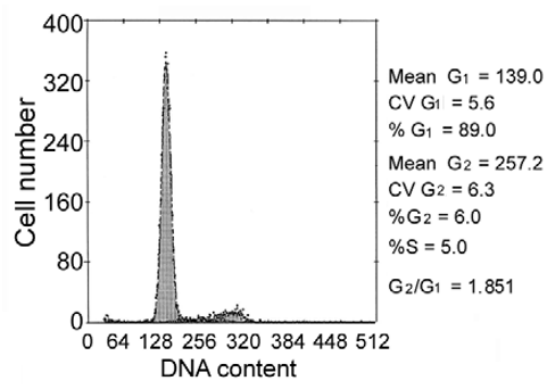

B

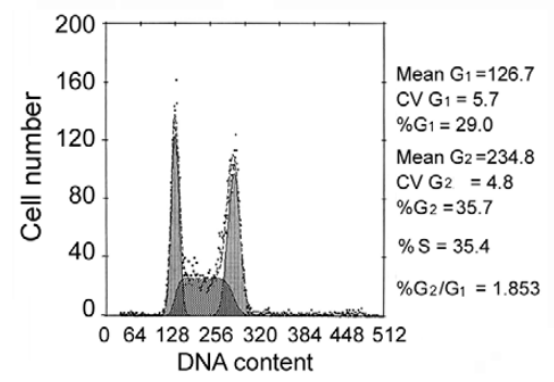

E

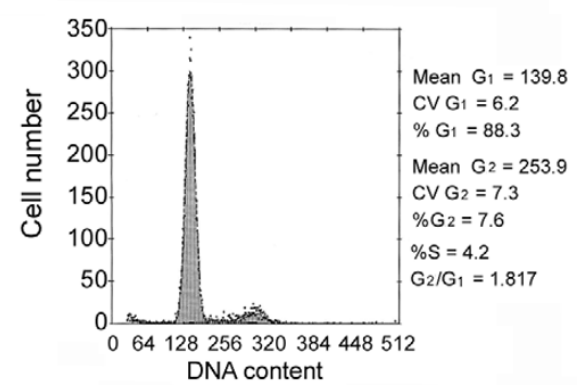

C

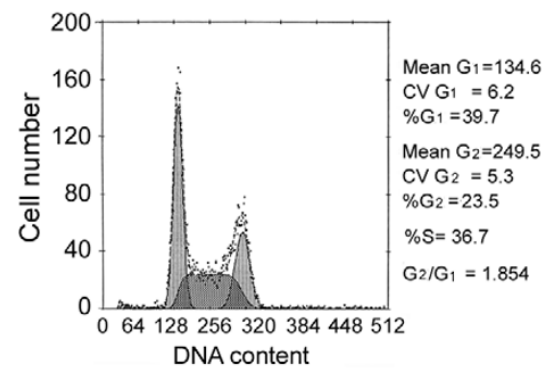

$\mathrm{F}$

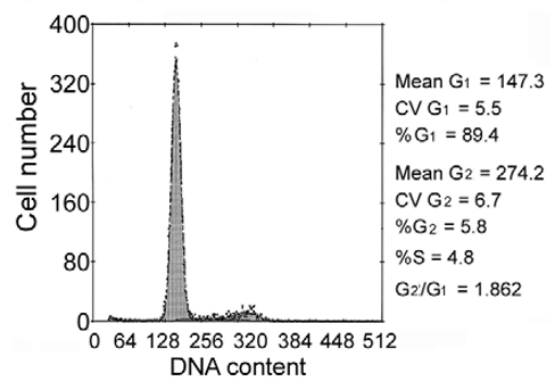

Fig 3. FCM analysis of SW1116 cells. TSA or sodium butyrate or combination treatment of TSA/sodium butyrate with 5-aza-dC induces the arrest of $\mathrm{G}_{1}$ to $\mathrm{S}$ phase in SW1116 cells. (A) mock treated, control; (B) ethanol control; (C) 5-aza-dC treated; (D) TSA treated; (E) sodium butyrate treated; (F) TSA + 5-aza-dC treated; (G) sodium butyrate + 5aza-dC treated.

TSA or sodium butyrate could induc the accumulation of $c$-myc gene mRNA (Tab 3). Taken together, the 5-aza-dC and TSA or sodium butyrate-induced changes in methylation and histone acetylation were localized at specific regions of the chromatin. Other mechanisms might explain a possibility in controlling the activity of the $c-m y c$ gene in colon cancer cell lines Colo-320 and SW1116. In addition, the effect of regulation of epigenetic modification on the expression of $p 53, p 73, c$-Ki-ras and survivin was not found (data not shown).

\section{TSA or sodium butyrate induces cell cycle arrest}

To address whether demethylation or acetylation of $p 21^{\text {WAFI }}$ affects the cell cycle, FCM was performed as described above. As expected, the data demonstrated a significant accumulation of cells in the $\mathrm{G}_{1}$ and $\mathrm{G}_{2}$ phases, and a decrease in the S-phase, thus indicating that either TSA or sodium butyrate induced cell cycle arrest in these two cell lines. Tab 4 further elucidated the association be- tween hypoacetylation and the cell cycle, showing that the ratio of the cell number in $\mathrm{G}_{1} / \mathrm{G}_{0}$ increased significantly, and that in the $\mathrm{G}_{2} / \mathrm{M}$ and S-phases it decreased. Interestingly, 5-aza-dC-treated SW1116 cells did not present comparable cell cycle arrest although 5-aza-dC induced the restoration of $C D K N 2 A$ expression; also there was no correlation between $C D K N 2 A$ gene expression and changes in the cell cycle of SW 1116 cells (see representative examples in Fig 3).

Taken together, these results suggested that due to the lack of $p 21^{\text {WAFI }}$ expression in human colon cancer cells, and hence an absence of $\mathrm{G}_{1}$-phase arrest in the cells, the genes were re-expressed after treatment with TSA or sodium butyrate. Similar results were obtained from another colon cancer cell line, Colo-320 (data not shown).

\section{DISCUSSION}

DNA methylation and chromatin modification are two global mechanisms for regulating gene expression. $\mathrm{CpG}$ 
island chromatin is found to contain highly acetylated histones $\mathrm{H} 3$ and H4[37]. The process of DNA methylation mediated by Dnmt1 may depend on the generation of an altered chromatin status via histone deacetylase activity [38]. Many investigators showed that genes silenced by the promoter hypermethylation could be reactivated by treatment with the demethylating drug 5-aza-dC, either alone or in combination with an HDAC inhibitor[31, 39], suggesting that DNA methylation and chromatin architecture act together to silence genes. Furthermore, TSA induces $\mathrm{G}_{0} \rightarrow \mathrm{G}_{1}$ cell cycle arrest[40].

Several studies indicate that $C D K N 2 A$ is hypermethylated in colon cancer cells[41], and 5-aza-dC-induced growth inhibition may result from the release of methylation silencing of the cell cycle regulatory genes, $C D K N 2 A[42]$. However, it remains unclear whether histone acetylation regulates the transcription of $C D K N 2 A$ and $A P C$ genes. Our finding that 5 -aza-dC but not TSA or sodium butyrate induces the transcription of $C D K N 2 A$ and $A P C$, suggests that DNA methylation rather than histone acetylation is the major regulation mechanism for these two genes in Colo320 and SW1116 cells. We noted that 5-aza-dC enhanced $C D K N 2 A$ transcription, but the combination of 5-aza-dC and TSA did not induce more expression of $C D K N 2 A$. It is possible that apoptotic cell deaths occurred when cells were treated by a combination of demethylation and TSA [43]. However, for $p 21^{\text {WAF1 }}$, either TSA or the combination of TSA and 5-aza-dC exhibits a 17- to 30-fold (Colo320 cells) or 3 - to 6 -fold (SW1116 cells) increase in transcription, suggesting that synergic gene activation occurs (Tab 3). Regarding the mechanism of sensitization mentioned above, these data indicated that the deme thylation of the gene promoters and the activity of 5-aza-dC could have complex effects on the localization and activity of HDACs that had not been previously contemplated[44].

Butyrate is known to alter the expression of a variety of genes by modulating histone acetylation[45-47]. Both sodium butyrate and TSA were shown to inhibit HDAC, leading to hyperacetylation of selective histone proteins such as histone $\mathrm{H} 4$ [46]. However, most previous studies have demonstrated that the transcription of $p 21^{\text {WAF1 }}$ could be strongly enhanced by TSA in the colon cancer cell line, HT29 [48], but have not elucidated the expression status of this gene during the treatment of 5-aza-dC or HDAC inhibitors in the human colon cancer cell lines Colo-320 and SW1116. As summarized in Tab 3 and 4, the hyperacetylation of histone but not demethylation induced the reexpression of $p 21^{W A F 1}$ and $\mathrm{G}_{1}$-phase arrest of Colo-320 and SW1116 cells. We also implied that either TSA or sodium butyrate or in combination with 5 -aza-dC, but not 5aza-dC alone, could induce $p 21^{W A F 1}$ expression. We used real-time quantitative PCR based on TaqMan methodol- ogy to analyze quantitatively the expression of these genes in routinely processed cells and demonstrated that the measurements of gene expression could be reliably and accurately conducted in such cells.

The inhibition of proliferation demonstrated a significant accumulation of cells in the $\mathrm{G}_{1}$ and $\mathrm{G}_{2}$ phases, and a decrease of cells in the S-phase of the two TSA-treated cell lines. TSA and sodium butyrate-induced growth inhibition could result from the release of hypoacetylation silencing of the cell cycle regulatory genes such as $p 21^{W A F 1}$. We also examined whether the re-expression of $C D K N 2 A$ induced by promoter hypomethylation could induce the arrest of the cell cycle similar to that by $p 21^{\text {WAF1 }}$ in human colon cancer cells. The result was negative. Data from this report supports the idea that $p 21^{W A F 1}$ expression is more important than $C D K N 2 A$ for the regulation of the cell cycle in the human colon cancer cell lines Colo-320 and SW1116.

Although reduced levels of methylation of genes including $c$-myc in human tumors have also been reported, it has not been shown convincingly that they are indeed responsible for increased levels of gene expression rather than merely a secondary characteristic observed in cancer cells. Overexpression and abnormal intracellular location of the product of the proto-oncogene $c-m y c$ in colon dysplasia and neoplasia may be related to alterations in epigenetic mechanisms which controll the function of this gene[49]. $p 73$ is a new member of the $p 53$ family. The transcriptional silencing of the $p 73$ gene by hypermethylation of a $\mathrm{CpG}$ island was observed in several leukemia and lymphomas [50]. Survivin is the first apoptosis inhibitor described todate to be expressed in $\mathrm{G}_{2}-\mathrm{M}$, in a cell cycle-dependent manner[45] and is detected in all cases of normal colon mucosa. Up to now, little is known about the relevance between the methylation and transcriptional level of $c-m y c$, p53[47], p73 and survivin genes during colon carcinogenesis or human colon cancer cell lines. Therefore, the coexistence of methylated and unmethylated status of several tumor suppressor genes and proto-oncogenes in the same colon cancer cell line, reflects the in vitro situation and has some functional significance.

The effect of the promoter methylation of several tumor- associated genes and histone acetylation of $p 21^{\text {WAF1 }}$ and $C D K N 2 A$ transcription have been analyzed in human colon cancer cell lines Colo-320 and SW1116. In this study, the results from RT-PCR and real-time RT-PCR indicate first that $C D K N 2 A, A P C, p 53, p 73$, survivin and $c$-myc, $c$-Ki-ras are expressed in Colo-320 and SW1116 cell lines. Furthermore, epigenetic modification did not seem to be involved in the transcription regulation of $p 53$, p73, survivin and $c-m y c, c-K i$-ras genes in these two cell lines.

One of the most important findings from this study is that neither DNA methyltransferase inhibitor nor HDAC 
inhibitor regulates the transcription of $c$-myc and $c$-Ki-ras proto-oncogenes in colon cancer cell lines Colo-320 and SW1116, although $c-m y c$ [51] and $c$-Ki-ras [52] were overexpressed in most human colon cancer. Previous clinical trials indicated that 5-aza-dC was devoid of anti-tumour activity in adult patients with colon cancer[53-55]. The data in present study suggests that the reason for its failing in colon cancer treatment is not $c-m y c$ over-expression from demethylation.

In conclusion, the major findings of this present study support the concept that histone acetylation but not methylation is the major mechanism in the regulation of $p 21^{W A F 1}$ gene expression, whereas methylation regulates the expression of $C D K N 2 A$ and $A P C$. The transcription level of $p 53, p 73, c-m y c, c-K i$-ras and survivin tumor associated genes are regulated by either methylation or histone acetylation in human colon cancer cell lines Colo320 and SW1116. Our results not only enhance our understanding of the molecular epigenetic mechanisms underscoring colon carcinogenesis, but also facilitate the development of diagnostic tools based on the DNA methylation profile and histone acetylation status for the early diagnosis of human colon cancer.

\section{ACKNOWLEDGEMENTS}

We thank Ms. Hong Yu LUO and Ms. Guan Feng SHEN for performing the FCM, and Dr. Xie Ning WU for his assistance in preparing this manuscript. This work was supported in part by National Natural Science Foundation of China (No. 30170413), the Foundation for Jing Yuan FANG of National Excellent Doctoral Dissertation of China (No. 199946) and the Foundation of Shanghai Education Committee (Shuguang Plan, No. 02SG45).

Received, Oct 15, 2003

Revised, Apr 17, 2004

Accepted, Apr 20, 2004

\section{REFERENCES}

1 Russo P, Malacarne D, Falugi C, Trombino S, O'Connor PM. RPR-115135, a farnesyltransferase inhibitor, increase 5-FUcytotoxicity in ten human colon cancer cell lines: Role of $\mathrm{p} 53$. Int J Cancer 2002; 100:266-75.

2 Mori H, Niwa K, Zheng Q, et al. Cell proliferation in cancer prevention; effects of preventive agents on estrogen-related endometrial carcinogenesis model and on an in vitro model in human colorectal cells. Mutat Res 2001; 480-481:201-7.

3 Ding X, Flatt PR, Permert J, Adrian TE. Pancreatic cancer cells selectively stimulate islet beta cells to secrete amylin. Gastroenterology 1998; 114:130-8.

4 Rylova SN, Amalifitano A, Persaud-Sawin DA, et al. The CLN3 gene is a novel molecular target for cancer drug discovery. Cancer Res 2002; 62:801-8.

5 Gao Z, Fields JZ, Boman BM. Tumor-specific expression of anti-mdr1 ribozyme selectively restores chemosensitivity in multidrug-resistant colon- adenocarcinoma cells. Int J Cancer 1999; 82:346-52.

6 Shiraki K, Tsuji N, Shioda T, Isselbacher KJ, Takahashi H. Expression of Fas ligand in liver metastases of human colonic adenocarcinoma. Proc Natl Acad Sci USA 1997; 94:6420-5

7 Mateyak MK, Obaya AJ, Sedivy JM. C-myc regulates cyclin DCdk4 and -Cdk6 activity but affects cell cycle progression at multiple independent points. Mol Cell Biol 1999; 19:4672-83

8 Nagai MA, Habr-Gama A, Oshima CT, Brentani MM. Association of genetic alterations of c-myc, c-fos, and c-Ha-ras protooncogenes in colorectal tumors. Frquency and clinical significance. Dis Colon Rectum 1992; 35:444-51.

9 van Es JH, Giles RH, Clevers HC. The many faces of the tumor suppressor gene APC. Exp Cell Res 2001; 264:126-34

10 O'Leary JJ, Landers RJ, Crowley M, et al. Alterations in exon 1 of c-myc and expression of p62 c-myc in cervical squamous cell carcinoma. J Clin Pathol 1997; 50:896-903.

11 Serrano M, Hannon GJ, Beach D. A new regulatory modif in cellcycle sontrol causing specific inhibition of cyclin D/CDK4. Nature 1993; 366:704-7.

12 Xiong Y, Zhang H, Beach D. Subunit rearrangement of the cyclindependent kinases is associated with cellular transformation. Genes Dev 1993; 7:1572-83.

13 Matsuoka S, Edwards MC, et al. p57 $7^{\mathrm{KIP} 2}$, a structurally distinct member of the $\mathrm{p} 21^{\mathrm{CIP} 1} \mathrm{Cdk}$ inhibitor family, is a candidate tumor suppressor gene. Genes Dev 1995; 9:650-62

14 Polyak K, Lee MH, Erdjument-Bromage H, Koff A, et al. Cloning of $\mathrm{p} 27^{\mathrm{Kip} 1}$, a cyclin-dependent kinase inhibitor and potential mediator of extracellular antimitogenic signals. Cell 1994; 78:59-66.

15 Kim JS, Lee S, Lee T, Lee YW, Trepel JB. Transcriptional activation of $\mathrm{p} 21^{\mathrm{WAF} 1 / \mathrm{CIP} 1}$ by apicidin, a novel histone deacetylase inhibitor. Biochem Biophy. Res Comm 2001; 281:866-71.

16 Mateyak MK, Obaya AJ, Sedivy JM. C-myc regulates cyclin DCdk4 and -Cdk6 activity but affects cell cycle progression at multiple independent points. Mol Cell Biol 1999; 19:4672-83.

17 Baylin SB, Herman JG, Graff JR, Vertino PM, Issa JP. Alterations in DNA methylation:a fundamental aspect of neoplasia. Adv Cancer Res 1998; 72:141-96.

18 Plass C. Cancer epigenomics.Human Mol Genet 2002; 11:2479- 88.

19 Fang JY, Xiao SD. Alteration of DNA methylation in gastrointestinal carcinogenesis. J Gastroenterol Hepatol 2001; 16:960-8.

20 Vettese-Dadey M, Grant PA, Hebbes TR, Crane- Robinson C, et al. Acetylation of histone $\mathrm{H} 4$ plays a primary role in enhancing transcription factor binding to nucleosomal DNA in vitro. EMBO J 1996; 15:2508-18.

21 Herman JG, Merlo A, Mao L, et al. Inactivation of the CDK2/ p16/MTS1 gene is frequently associated with aberrant DNA methylation in all common human cancers. Cancer Res 1995; 55: 4525-30.

22 Gonzalez-Zulueta M, Bender CM, Yang AS, et al. Methylation of the 5' $\mathrm{CpG}$ island of the p16/CDKN2 tumor suppressor gene in normal and transformed human tissues correlates with gene silencing. Cancer Res 1995; 55:4531-5.

23 Burri N, Shaw P, Bouzourene H, et al. Methylation silencing and mutations of the p14ARF and p16INK4a genes in colon cancer. Lab Invest, 2001; 81:217-29.

24 Struhl K. Histone acetylation and transcriptional regulatory mechanisma. Genes Dev 1998; 12:599-606.

25 Yoshida M, Kijima M, Akita M, Beppu T. Potent and specific 
inhibition of mammalian histone deacetylase both in vivo and in vitro by trichostatin A. J Biol Chem 1990; 265:17174-9.

26 Xiao H, Hasegawa T, Isobe KI. p300 collaborates with Sp1 and $\mathrm{Sp} 3$ in $\mathrm{p} 21^{\text {waf } 1 / \mathrm{cip} 1}$ promoter activation induced by histone deacetylase inhibitor. J Biol Chem 2000; 275:1371-6.

27 Xiao H, Hasegawa T, Isobe KI. Both sp1 and sp3 are responsible for $\mathrm{p} 21^{\text {wafl }}$ promoter actvity induced by histone deacetylase inhibitor in HIH3t3 cells. J Cell Biochem 1999; 73:291-302.

28 Archer SY, Hodin RA. Histone acetylation and cancer. Current Opinion in Genetics \& Development 1999; 9:171-4.

29 Siavoshian S, Segain JP, Kornprobst M, et al. Butyrate and trichostain A effects on the proliferation/ differentiation of human intestinal epithelial cells: induction of cyclin D3 and p21 expression. Gut 2000; 46:507-14.

30 Fang JY, Mikovits JA, Bagni R, Petrow-Sadowski CL, Ruscetti FW. Infection of lymphoid cells by integration-defective human immunodeficiency virus type 1 increases de novo methylation. $\mathrm{J}$ Virol 2001; 75:9753-61.

31 Juttermann R, Li E, Jaenisch R. Toxicity of 5-aza-2'-deoxycytidine to mammalian cells is mediated primarily by covalent trapping of DNA methyltransferase rather than DNA demethylation. Proc Natl Acad Sci USA 1994; 91:11797-801.

32 Xiong Z, Laird PW. COBRA: a sensitive and quantitative DNA methylation assay. Nucleic Acids Res 1997; 25:2532-4.

33 Richon VM, Sandhoff TW, Rifkind RA, Marks PA Histone deacetylase inhibitor selectively induces p21WAF1 expression and gene-associated histone acetylation. Proc Natl Acad Sci USA 2000; 97:10014-9.

34 Magdinier F, Wolffe AP. Selective association of the methylCpG binding protein MBD2 with the silent p14/p16 locus in human neoplasia. Proc Natl Acad Sci USA 2001; 98:4990-5.

35 Scanlan MJ, Welt S, Gordon CM, et al. Cancer-related serological recognition of human colon cancer: identification of potential diagnostic and immunotherapeutic targets. Cancer Res 2002; 62: 4041-7.

36 Bender CM, Gonzalgo ML, Gonzales FA, et al. Role of cell division and gene transcription in the methylation of $\mathrm{CpG}$ islands. Mol Cell Biol 1999; 19:6690-8.

$37 \mathrm{Ng} \mathrm{HH}$, Bird A. DNA methylation and chromatin modification. Current Opinion in Genetics \& Development 1999; 9:158-63

38 Fuks F, Burgers WA, Brehm A, Hughes-Davies L, Kouzarides T. DNA methyltransferase DNMT1 associates with histone deacetylase activity. Nat Genet 2000; 24:88-91.

39 Zhu WG, Dai Z, Ding H, et al. Increased expression of unmethylated CDK2D by 5-aza-2'-deoxycytidine in human lung cancer cells. Oncogene, 2001; 20:7787-96.

40 Bordonaro M, Mariadason JM, Aslam F, Heerdt BG, Augenlicht LH. Butyrate induced cell cycle arrest and apoptotic cascade in colonic carcinoma cells: modulation of the $\beta$-catenin-Tcf pathway, and concordance with effects of sulindac and trichostatin, but not curcumin. Cell Growth Differ 1999; 10:713-20.
41 Bariol C, Suter C, Cheong K, et al. The relationship between hypomethylation and $\mathrm{CpG}$ island methylation in colorectal neoplasia. Am J Pathol 2003; 162:1361-71.

42 Bender CM, Pao MM, Jones PA. Inhibition of DNA methylation by 5-aza-2'-deoxycytidine suppresses the growth of human tumor cell lines. Cancer Res 1998; 58:95-101.

43 Zhu WG, Lakshmanan RR, Beal MD, Otterson GA. DNA Methyltransferase Inhibition Enhances Apoptosis Induced by Histone Deacetylase Inhibitors. Cancer Res 2001; 61:1327-33.

44 Baylin SB, Esteller M, Rountree MR, et al. Aberrant patterns of DNA methylation, chromatin formation and gene expression in cancer. Human Mol Genetics 2001; 10:687-92.

45 Johnstone RW. Histone-deacetylase inhibitors: novel drugs for the treatment of cancer. Nat Rev Drug Discov 2002; 1:287-99.

46 Yoshida M, Normura S, Beppu T. Effects of trichostatin on differentiation of murine erythroleukemia cells. Cancer Res 1987; 47:3688-91.

47 Allan LA, Duhig T, Read M, Fried M. The p21(WAF1/CIP1) promoter is methylated in Rat-1 cells: stable restoration of p53dependent $\mathrm{p} 21$ (WAF1/CIP1) expression after transfection of a genomic clone containing the $\mathrm{p} 21$ (WAF1/CIP1) gene. Mol Cell Biol 2000; 20:1291-8.

48 Della Ragione F, Criniti V, Pietra VD, et al. Genes modulated by histone acetylation as new effectors of butyrate activity. FEBS Lett 2001; 499:199-204.

49 Hague A, Elder DJE, Hicks DJ, Paraskeva C. Induction by the short chain fatty acids butyrate, propionate and acetate and by the bile salt deoxycholate. Int J Cancer 1995; 57:400-6.

50 Hague A, Manning AM, Hanlon KA, et al. Sodium butyrate induces apoptosis in the human colonic tumor cell line in a p53independent pathway: implications for the possible role of dietary fiber in the prevention of large bowel cancer. Int J Cancer 1993; 55:498-505.

51 Bourgarel-Rey V, El Khyari S, Rimet O, et al. Opposite effects of antimicrotubule agents on c-myc oncogene expression depending on the cell lines used. Eur J Cancer, 2000; 36:1043-9.

52 Schramm K, Krause K, Bittroff-Leben A, Goldin-Lang P, Kreuser $\mathrm{ED}$. Activated K-ras is involved in regulation of integrin expression in human colon carcinoma cells. Int J Cancer 2000; 87:155-64.

53 Moertel CG, Schutt AJ, Reitemeier RJ, Hahn RG. Phase II study of 5-azacytidine (NSC-102816) in the treatment of advanced gastrointestinal cancer. Cancer Chemother Rep 1972; 56:649-52.

54 Bellet RE, Mastrangelo MJ, Engstrom PF, et al. Clinical trial with subcutaneously administered 5-azacytidine (NSC-102816). Cancer Chemother Rep 1974; 58:217-22

55 Abele R, Clavel M, Dodion P, et al. The EORTC Early Clinical Trials Cooperative Group experience with 5-aza-2'-deoxycytidine (NSC 127716) in patients with colo-rectal, head and neck, renal carcinomas and malignant melanomas. Eur J Cancer Clin Oncol 1987; 23:1921-4. 